Marquette University

e-Publications@Marquette

$1-1-2006$

\title{
The Impact of Financial Openness on Economic Integration: Evidence from Europe and the CIS
}

Fabrizio Carmignani

University of Queensland

Abdur Chowdhury

Marquette University, abdur.chowdhury@marquette.edu

Published version. "The Impact of Financial Openness on Economic Integration: Evidence from Europe and the CIS," in Return to Growth in CIS Countries. Eds. Lúcio Vinhas de Souza and Oleh Havrylyshyn. Berlin: Springer, 2006: 281-299. DOI. (C 2006 Springer. 


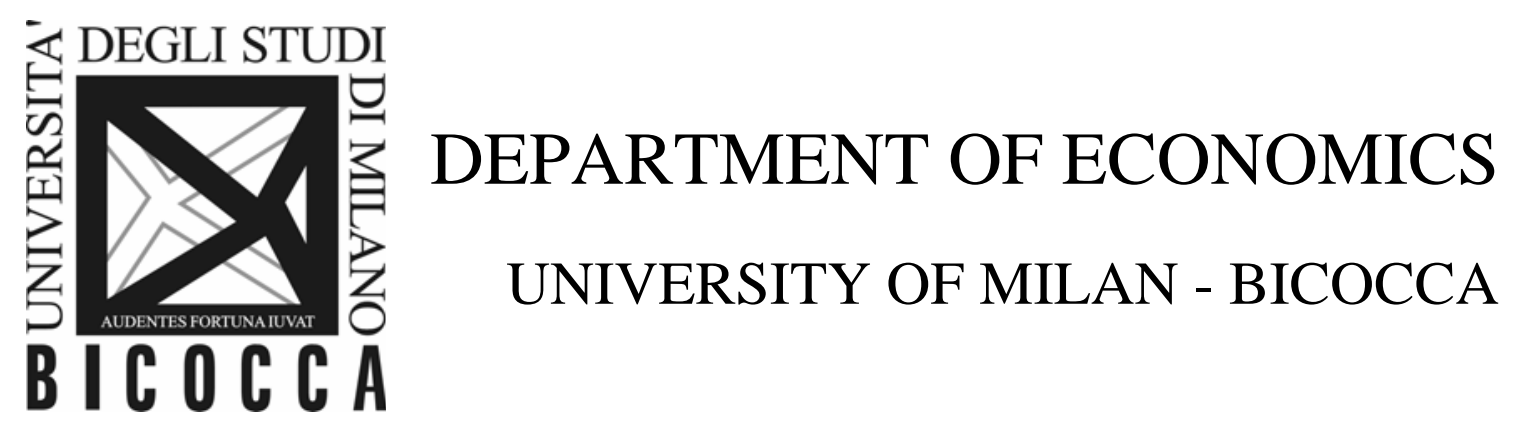

\section{WORKING PAPER SERIES}

\section{The Impact of Financial Openness on Economic Integration: Evidence from the Europe and the Cis}

Fabrizio Carmignani, Abdur Chowdhury

No. 88 - April 2005 


\title{
THE IMPACT OF FINANCIAL OPENNESS ON ECONOMIC \\ INTEGRATION: EVIDENCE FROM THE EUROPE AND THE CIS
}

\author{
Fabrizio Carmignani and Abdur Chowdhury*
}

11 April 2005.

\begin{abstract}
We study whether financial openness facilitates the economic integration of formerly centrally planned economies with the EU-15. Two dimensions of economic integration are considered: cross-country convergence of per-capita incomes and bilateral trade in goods and services. We find that more financially open economies effectively catch-up faster and trade more with the EU-15. These integrationenhancing effects occur over and above any effect stemming from domestic financial deepening and other factors determining growth and trade.
\end{abstract}

Keywords: Economic integration, financial openness, gravity models, catching-up

JEL Classification: F10, F15, F30, F36, F40

\footnotetext{
* Both authors are with the Economic Analysis Division, United Nations Economic Commission for Europe (UNECE), Palais des Nations, 8-14 Avenue de la Paix, CH-1211 Geneva 10, Switzerland. Emails: fabrizio.carmignani@unece.org, abdur.chowdhury@unece.org. We acknowledge helpful comments from our colleagues at the Economic Analysis Division. Christine Wolfgramm provided excellent research assistance. We are solely responsible for any errors and inconsistencies. The views expressed in the paper are our own and do not necessarily reflect those of UNECE Secretariat.
} 


\section{Introduction}

The widespread progress on capital account liberalization, the massive increase in financial flows across the borders, and the financial crises that hit emerging economies in the '90s have stimulated a lively debate on the broad economic effects of financial openness. This paper contributes to the debate by assessing whether financial openness facilitates international trade in goods and services and per-capita income catching-up across countries in Europe and the CIS. As the current wave of globalization has generated widespread interest among national policymakers on the factors and policies that best promote economic integration, the paper provides empirical evidence on whether financial openness should be included among such policies by focusing on two of the dimensions that most critically characterise the process of economic integration, namely international trade and income convergence. Several features characterise this paper relative to the existing literature. First, the analysis specifically separates the concept of financial openness from that of international financial integration. These two terms have often been used interchangeably in the literature, but, in fact, they represent a mean-goal relationship ${ }^{1}$. Financial openness is the process of lifting administrative or legal restrictions on capital movements and hence creating the necessary conditions for the integration of the domestic financial system into the global market. Thus, financial openness is essential to achieve international financial integration, but the former does not necessarily lead to the latter. Operationally, the analysis in this paper will employ different empirical proxies: financial openness will be measured by an index of capital account restrictions while international financial integration will be measured by portfolio-based and equity-based capital flows.

Second, specific attention will be devoted to disentangling the effect of financial openness from that of domestic financial development. As the two phenomena are expected to be positively correlated, the variables used to proxy for financial openness might also capture the effect of domestic financial development on the economic performance. The consequence might be the overestimation of the actual impact of financial openness. To address this problem, the econometric model will include

\footnotetext{
${ }^{1}$ See, for instance, the discussions in De Brouwer (1999) and Le (2000).
} 
indicators of the depth of domestic financial markets in addition to measures of financial openness ${ }^{2}$.

Third, most of the literature on the effects of financial openness (or financial integration) on economic performance essentially looks at economic growth ${ }^{3}$. This paper instead directly considers the income difference between rich and poor countries, thus assessing the differential impact of financial openness on the speed of catching-up. Moreover, in studying the contribution of financial openness to international trade, this paper extends the existing literature on trade empirics by considering variables not included in previous studies which used gravity equations ${ }^{4}$. Finally, our investigation looks at two groups of countries: the formerly centrally planned economies (referred as "emerging economies") and a broader set of 44 countries from eastern and western Europe, North America and the CIS ${ }^{5}$. In both the groups, there are clear incentives toward forms of regional cooperation and integration. In this sense, our paper is linked to the fast growing literature on regional economic integration ${ }^{6}$.

The key results of the analysis can be summarised as follows. Financial openness, that is the degree to which international capital movements are not restricted, significantly facilitates per-capita income catching-up and trade integration. The trade effect is particularly evident in the group of emerging economies. Moreover, these effects of financial openness appear to work over and above any effect stemming from the development of domestic financial systems. Finally, the effective degree of involvement of domestic markets into global financial links (i.e. the degree of international financial integration) also promotes economic integration in both groups. The rest of the paper is organised as follows. Section 2 briefly surveys the theoretical hypothesis on the impact of financial openness on the two dimensions of economic

\footnotetext{
${ }^{2}$ Guiso et al. (2004) provides an in-depth analysis of the link between financial development and financial integration focusing on the EU countries. They claim that most of the growth pay-off from financial integration occurs through domestic financial development.

${ }^{3}$ See Hali et al. (2004) for a survey.

${ }^{4}$ Rose (2004) surveys the variables and channels that are most often investigated in the literature on the macroeconomic determinants of international trade.

${ }^{5}$ This second group coincides with the membership of the United Nations Economic Commission for Europe and it is therefore characterised by some significant degree of cooperation and integration on socio-economic matters

${ }^{6}$ For a recent overview of this literature see Schiff and Winters (2003).
} 
integration. Section 3 introduces the econometric methodology and explains the specification of the model. Section 4 discusses the results. Section 5 concludes, drawing some policy implications and pointing to future lines of research. Tables and variables are presented in the Appendix.

\section{Some theoretical background.}

This paper evaluates the effect of financial openness on two dimensions of economic integration: international trade in goods and services and convergence of per-capita income across countries. The theoretical underpinnings of the analysis are spelled out in this section.

\subsection{Financial openness and convergence of per-capita income.}

Economic growth theory provides the rationale for linking financial openness (and financial integration) to per-capita income. In both neo-classical and endogenous growth models, per-capita income at a generic time $t$ is determined by technology and rates of accumulation of production factors (labour, physical and human capital) ${ }^{7}$. Several arguments have been proposed in the literature to argue that financial openness has an impact on such determinants of per-capita income.

One channel points to possible technological spillovers arising from capital account liberalisation which spurs capital inflows and investments from abroad. Related arguments emphasise the spillovers eventually stemming from transfers of skills and increased competition. Another strand of research suggests that financial openness will broaden risk-sharing opportunities for domestic investors, thus reducing the cost of equity capital and hence increasing investment and the rate of capital accumulation. Moreover, better risk-sharing options will allow countries to shift their investment mix towards riskier and hence higher-return projects. On a different ground, the political economy literature has pointed out the role of financial openness as a commitment technology device. When economic policies are dynamically inconsistent, capital account liberalization signals government's intention to stick to macroeconomic and financial discipline. This in turn reduces economic uncertainty and hence favours longer-term investment and factors accumulation. Finally, financial

\footnotetext{
${ }^{7}$ For a formal treatment of the neo-classical model see Mankiw et al. (1992). For a review of models of endogenous growth see Barro and Sala-i-Martin (1995, Chapters 4 and 5).
} 
openness might be linked to income growth via the domestic financial system. In this view, lifting capital account restrictions promotes faster development of the domestic financial intermediation leading to a greater volume of credit being available to finance profitable projects as well as higher efficiency in the allocation of resources ${ }^{8}$.

The central message of this literature is that financial openness positively correlates with per-capita income (and with the rate of economic growth). Hence, the implication is that if a country maintains capital account restrictions and limits the degree of international integration of its financial markets, then it will experience a widening gap in per-capita income relative to a partner which is more financially open. That is, for a given level of financial openness of the partner country, the income gap between the partner country and the domestic country will be greater the lower the degree of financial openness of the domestic country.

However, this prediction does not go unchallenged. Several models emphasise possible counter-effects of financial openness on income which might, in turn, complicate the relationship between financial openness and income catching-up. If domestic institutions are weak, increasing financial openness will lead to a capital flight (even if the country is capital-scarce). This will hamper investment and hence long term growth prospects. Similarly, since the capital account is a channel of contagion in financial crises, its liberalization will make the country more vulnerable to speculative attacks, sudden stops and capital reversal, which are in turn all likely to have large negative output effects. Finally, informational asymmetries and/or preexisting distortions (such as trade restrictions) might well imply that foreign capitals will be allocated inefficiently, for instance going to sectors where the country has a comparative disadvantage 9 . All of these counter-arguments thus point to the possibility that an increase in financial openness might in fact have perverse effects on the income gap of the domestic country relative to richer partners.

\footnotetext{
${ }^{8}$ Bailliu (2000) proposes a simple formalization of several links between financial openness and growth within an AK setting. Bekaert and Lundbland (2001) and Henry (2003) discuss the effect of financial openness on the cost of capital. Obstfeld (1994) shows that financial openness, when resulting in capital market integration, supports risk-taking. Bartolini and Drazen (1997) examine the argument that capital account liberalization can work as a signal.

${ }^{9}$ See Boyd and Smith (1992) for a critics of the perverse effects of financial openness when domestic institutions are inefficient. A sceptical view of capital account liberalization based on various arguments is put forward by Rodrik (1998). The empirical literature also provides mixed evidence on the growth-effects of financial liberalization. For a broad assessment see Eichengreen (2001).
} 


\subsection{Financial openness and international trade}

Assuming that internationally well integrated capital markets will effectively emerge from it, financial openness can influence the extent of international trade in goods and services through two main channels. The first operates through risk-sharing and production specialization ${ }^{10}$. Consider a region where countries are affected by idiosyncratic shocks. If such shocks are large and volatile, or alternatively if households are risk averse to a sufficient degree, then incentives to diversify domestic production will be stronger, thus leading to low specialization. Open and well integrated financial markets facilitate the diversification of ownership. This in turn has two effects. First, if economic agents in one country hold debt and equity claims on the output of the other country, then the dividend, interest and rental income derived from these holdings contributes to smoothing shocks across countries. This is thus a form of ex-ante international insurance. Second, to achieve consumption smoothing, households in each country will undertake ex-post adjustment of their asset portfolios following the realization of idiosyncratic shocks in the region. Again, this will lead to smoothing the income of all countries. Once insurance is available through international trade in financial assets, each country will have stronger incentive to specialize in one production (or technology) in order to fully exploit economies of scale (or technological competitive advantage). Specialization in production will then create greater scope for international trade in goods and services, as predicted from a standard neo-classical trade theory.

The second channel relies on the ability of the financial sector to divert savings to the private sector. When domestic financial intermediation is weak and inefficient, firms in export-oriented sectors are burdened by significant liquidity constraints and hence trade less. Financial openness can help overcome those constraints by making more external finance available to domestic firms. An implication of this model is that international trade will tend to increase particularly in those sectors that more heavily rely on external finance, such as projects in the manufacturing sector. A related argument is that financial openness, by eventually facilitating the development of

\footnotetext{
${ }^{10}$ For a discussion of the theoretical and empirical link between capital markets, risk sharing and production specialization see Kalemli-Ozcan et al. (2003). For more empirical evidence see Imbs (2003).
} 
financial intermediation and hence contributing to the establishment of efficient systems of international payments, can work as a trade facilitation factor ${ }^{11}$.

Overall, with respect to international trade, the prediction on the effects of financial openness is that countries that are more financially open should experience greater volumes of international trade; that is, financial openness should facilitate country's trade integration with any partner.

\section{Methodology and data.}

Based on the discussion in Section 2, the paper estimates two equations. One links financial openness to the difference in per-capita income across countries; the other links financial openness to a country's international trade. Modelling strategy and estimation methodology are described below.

\subsection{Modelling strategy}

Lets' consider the income-gap equation first. The log of per-capita income $y$ in country $i$ at time $t$ is assumed to be a function of $K$ variables plus the degree of financial openness $z$ (as suggested by the arguments reviewed in Section 2):

(1) $y_{i t}=f\left(x_{1, i t}, x_{2, i t}, \ldots x_{K, i t}, z_{i t}\right)$

Denoting $j$ as the partner country, the income gap between $i$ and $j$ can be written as:

(2) $y_{j t}-y_{i t}=f\left(\left(x_{1, j t}-x_{1, i t}\right),\left(x_{2, j t}-x_{2, i t}\right), \ldots\left(x_{K, j t}-x_{K, i t}\right),\left(z_{j t}-z_{i t}\right)\right)$

For estimating equation (2), the regressors $x_{1} \ldots x_{K}$ on the r.h.s. need to be specified Using a technology-augmented Cobb-Douglas specification for the production function, a parsimonious set of regressors can be identified which includes (in logs): the rates of labor accumulation $(n)$, physical capital accumulation $(k)$ and human

\footnotetext{
${ }^{11}$ Kletzer and Bardhan (1987) provide a first formalization of the second channel. Further theoretical advances and some supporting empirical evidence are reported by Beck (2001).
} 
capital accumulation $(h)$ and a constant term $(c)^{12}$. The empirical model for income gap between country $i$ and country $j$ at time $t$ is thus given by:

(3) $d y_{t}=\alpha_{0}+\alpha_{1} d n_{t}+\alpha_{2} d h_{t}+\alpha_{3} d k_{t}+\alpha_{4} d z_{t}+\varepsilon_{t}$

where $d$ denotes the difference between country $j$ and country $i$ (i.e. $d y_{t}=y_{j t}-y_{i t} ; d n_{t}$ $=n_{j t}-n_{i t}$; and so forth), $\alpha_{0}=c_{j}-c_{i}, \varepsilon_{\mathrm{t}}$ is a normally distributed stochastic disturbance term, and the $\alpha$ 's are parameters to be estimated. Note that if $\alpha_{4}>0$, then the more country $i$ falls behind country $j$ in terms of financial openness, the larger the incomegap will be. This means that to reduce the income-gap, country $i$ will have to increase its degree of financial openness for any given degree of financial openness achieved by the partner $j$. The role of financial openness in the process of per-capita income convergence can thus be tested through the null hypothesis $\mathrm{H}_{0}: \alpha_{4}=0$.

Two modifications of equation (3) will be considered. First, as discussed in the introduction, it is important to separate the effect of financial openness from that of domestic financial development. For this purpose, a term $d q_{t}$, where $q$ is a proxy of the depth of domestic financial intermediation, will be added to equation (3). Second, as several theoretical models predict that financial openness will impact on per-capita income by directly affecting the rate of physical capital accumulation, the inclusion of the term $d k_{t}$ might bias the estimated $\alpha_{4}$ downward, thus leading to the conclusion that financial openness is not significant when it actually is. For this reason, equation (3) will be estimated both with and without $d k_{t}$. As it will turn out, the null hypothesis $\mathrm{H}_{0}$ $: \alpha_{4}=0$ is rejected in both cases.

The second equation estimated in this paper is a gravity model of bilateral trade. The gravity approach posits that the volume of trade between two partners is positively related to their economic size and inversely related to their distance. This approach has received wide empirical support and recent studies have shown how it can be closely linked to formal theories of international trade ${ }^{13}$. Therefore, it seems to be the most appropriate tool to test whether financial openness promotes trade integration.

\footnotetext{
${ }^{12}$ The underlying assumption being that technology grows at a constant rate and that its initial level is equal to a constant plus a white noise. See Mankiw et al. (1992).

${ }^{13}$ For a discussion of gravity equations, see, inter alia, Evenett and Keller (2002).
} 
For a given year $t$, the gravity equation expresses trade of country $i$ with the partner country $j\left(T_{i j}\right)$ as a function of the economic size of the two countries $(Y)$, the geographical distance between them $(D)$ and a set of additional geographical, economic and environmental variables $W$ :

(4) $T_{i j, t}=\frac{Y_{i, t} Y_{j, t}}{D_{i j, t}} \exp \left(W_{i j, t}\right)$

Taking logs on both sides, equation (4) becomes:

(5) $\ln \left(T_{i j, t}\right)=\ln \left(Y_{i, t} Y_{j, t}\right)-\ln \left(D_{i j, t}\right)+W_{i j, t}$

Following the arguments presented in Section 2, financial openness of country $i\left(z_{i}\right)$ will be included in the set $W$. Similarly to the specification of the per-capita income gap equation, a proxy for domestic financial depth in country $i$ will also enter the r.h.s. so as to disentangle the effect of financial openness from that of financial development. Thus, the gravity equation to be estimated is:

(6) $\ln \left(T_{i j, t}\right)=\beta_{0}+\beta_{1} \ln \left(Y_{i, t} Y_{j, t}\right)+\beta_{2} \ln \left(D_{i j, t}\right)+\beta_{3} z_{i, t}+\beta_{4} q_{i, t}+v_{i j, t}$

where $v$ is a stochastic disturbance term, and $\beta$ 's are the parameters to be estimated. It goes without saying that, whilst formally indexed by the subscript $t$, distance $D$ is constant over time. Again, the sign and statistical significance of the coefficient $\beta_{3}$ will provide empirical evidence on the impact of financial openness on the degree of trade integration of country $i$ with partner $j$. A statistically significant and positive value of $\beta_{3}$ would indicate that financial openness promotes trade integration.

Drawing on the gravity literature, equation (6) will also be expanded by adding some dummy variables to the set $W$ in order to isolate specific trade facilitating conditions.

\subsection{Estimation methodology and data}

\section{Sample and methodology}

Equations (3) and (6) are estimated on two groups of countries. The first group includes only formerly planned economies (so-called emerging economies). The 
second group consists of 44 countries, including industrial as well as emerging economies. The sample covers the period 1990-2003 ${ }^{14}$. Trade integration and percapita income convergence are estimated for each country $i$ vis-à-vis the European Union-15 (EU-15) average, which is therefore taken to be the reference partner. That is, in both equations, $j$ is represented by the EU-15 average. This makes it possible to assess the effect of financial openness on the process of economic integration of country $i$ with the EU-15. In fact, the main findings are qualitatively unchanged if the United States or the richest among EU-15 economies are used as reference partners.

To account for reverse causality; that is for the possibility that financial openness is determined by trade volumes and per-capita income growth, equations (3) and (6) will be estimated by 2 SLS, using lagged and initial values of endogenous variables as instruments. The estimator is further corrected to account for the fact that the annual panel is unbalanced. ${ }^{15}$

To operationalise equation (3), $y$ is measured by a country's real per-capita GDP, $n$ is proxied by the fertility rate, $h$ is proxied by the enrolment rate in tertiary schooling, $k$ is proxied by the real investment share of GDP, $q$ is defined as country's ratio of M2 minus narrow money to narrow money. In equation (6), instead, $T$ is measured by a country's exports to and imports from the EU-15 (in logs of millions USD), $Y$ is given by real aggregate GDP and $D$ is the log of distance (in kilometres) between a country and Frankfurt-am-Main. A complete list of variables, definitions and sources is given in the Appendix. Moreover, the next section will discuss the sensitivity of econometric results to changes in variables definition and construction.

\footnotetext{
${ }^{14}$ The panel is however unbalanced as for some countries the first available observation comes later than 1990. The group of emerging economies includes: Albania, Armenia, Azerbaijan, Belarus, Bulgaria, Croatia, Czech Republic, Estonia, Hungary, Kazakhstan, Kyrgyz Republic, Latvia, Lithuania, Moldova, Poland, Romania, Russian federation, Slovak Republic, Slovenia, Ukraine. The group f 44 economies includes all of the above emerging economies plus: Austria, Belgium, Canada, Cyprus, Denmark, Finland, France, Germany, Greece, Iceland, Ireland, Israel, Italy, Luxembourg, Malta, Netherlands, Norway, Portugal, Spain, Sweden, Switzerland, Turkey, United Kingdom, United States.

${ }^{15}$ The unbalanced panel estimator follows Verbeek and Nijman (1996). An alternative to the 2SLS instrumental variable estimator would be a 3SLS system estimator (see Wooldridge, 2002). In this case, equations (3) and (6) are estimated as a system together with an equation where financial openness is the dependent variable and trade and per-capita income enter as explanatory variables. In fact, a set of estimates from the 3SLS procedure are available from the authors upon request. The qualitative thrust of results does not change relative to the single-equation 2SLS presented in the next section. We prefer reporting the 2SLS and not the 3SLS because the focus of this analysis is more on the estimation of reduced-form equations than on structural models.
} 
Empirical definition of financial openness and international financial integration

Crucial to the estimation of equations (3) and (6) is the empirical definition of the variable $z$, the degree of financial openness. This should capture the extent to which a country does not restrict capital movements across borders. At the same time, however, it should not be based on the actual volume of cross-holdings of foreign assets and liabilities, as in this case it would be a measure of international financial integration rather than financial openness. A suitable strategy, indeed rather common in the literature, is to construct an index of capital account liberalisation using the information available from the IMF's Annual Report on Exchange Arrangements and Exchange Restrictions (AREAR) ${ }^{16}$. We follow the approach proposed by Chinn and Ito (2001) and construct our variable $z$ as follows.

From the AREAR we define for each country and each year four dummies: (i) $R_{1}$ takes value 1 in the absence of multiple exchange rates, (ii) $R_{2}$ takes value 1 if current account transactions are not restricted, and (iii) $R_{3}$ takes value 1 if capital account transactions are not restricted, (iv) $R_{4}$ takes value 1 in the absence of a requirement of surrender of export proceeds. A variable $\mathrm{SHARE}_{3}$ is then constructed for each year as the average of $R_{3}$ in that year and in the four preceding years. Finally, $z$ is obtained for each country and each year as the first standardised principal component of $R_{1}, R_{2}$, $S H A R E_{3}$ and $R_{4}$. Thus, $z$ is a indicator of overall cross-border capital liberalisation: higher values denote greater financial openness.

Equations (3) and (6) will also be estimated replacing the indicator of financial openness $z$ by two measures of international financial integration taken from Lane and Milesi-Ferretti (2003):

$p_{1, i t}=\frac{F A_{i t}+F L_{i t}}{G D P_{i t}} \quad$ and $\quad p_{2, i t}=\frac{P E A_{i t}+P E L_{i t}+F D I A_{i t}+F D I L_{i t}}{G D P_{i t}}$

where, as usual, $i$ denotes a country and $t$ a given year, $F A$ is the stock of foreign assets, $F L$ is the stock of foreign liabilities, PEA and PEL are the stocks of portfolio equity assets and liabilities respectively, FDIA and FDIL are the stock of foreign direct investment assets and liabilities respectively. Thus, the variable $p_{1}$ measures the

\footnotetext{
${ }^{16}$ See Miniane (2004) for a survey of various approaches adopted in the construction of such indices.
} 
overall volume of cross-holdings for a given country in a given year. The variable $p_{2}$ measures instead the volume of cross-holdings in equity.

\section{Econometric results}

\subsection{Financial openness and per-capita income-gaps.}

The results for the income gap equation are reported in Table 1. The estimates for the group of emerging economies are shown in columns I to IV; the estimates for the full sample of 44 countries are displayed in columns V to VIII.

Starting with emerging economies, column I reports the baseline specification of equation (3) without $d k$. The estimated coefficient on $d z$ is positive and statistically significant. This means that the more a country approaches the degree of financial openness of the EU-15, the smaller its income gap relative to the EU-15 average will be. The effect holds over and above the impact of differences in domestic financial depth and in the rates of factors accumulation. Columns II and III show the same baseline equation re-estimated with measures of gaps in the degree of international financial integration $\left(d p_{1}\right.$ and $\left.d p_{2}\right)$. The evidence is complementary to that in column I: countries that fall behind the EU-15 average in terms of their degree of international financial integration tend to experience greater income gaps. Finally, in column IV the gap in physical capital accumulation, $d k$, is included. A couple of interesting findings emerge. The coefficient on $d z$ remains positive and different from zero; actually, it substantially increases, whilst the coefficient on $d q$ decreases (even though it remains statistically significant at high confidence levels). Moreover, the effect of gaps in investment rates appear to be marginally very small. Taken all together, these findings suggest that in emerging economies financial openness impacts catching-up not only through its effect on the level of the investment rate in the economy and/or its contribution to domestic financial development. The discussion in Section 2 has in fact emphasised other possible channels, including investment-composition effects and productivity/technological spillovers.

Turning to sample of all countries, it is evident that results are qualitatively very similar to that reported for the group of emerging economies. If anything, the marginal effects of both financial openness and domestic financial development appear to be larger, as denoted by the point estimates in column V. Interestingly, the inclusion of $d k$ also leads to an increase in the coefficient on $d z$ and a contemporaneous decrease in the coefficient on $d q$. However, differently, from the 
case of emerging economies, the gap in the investment rate now has a significant impact on the income gap. Finally note that in both groups, the income gap significantly depends on the gap in the rate of human capital accumulation, whilst the gap in labour force accumulation appears to have no effect.

Various robustness checks have been performed to test the sensitivity of the results. First, to test for the impact of "absolute" rather than "relative" financial openness, the income-gap equation has been re-estimated using the level of $z$ rather than of $d z$ (and the same for $q$ and $d q$ ). In the basic specification without $d k$, the estimated coefficient on $z$ is -0.185 (significant at $5 \%$ ) for the emerging economies and -0.583 (significant at $1 \%$ ) for the full sample. Hence, as expected, countries that are more financially open in absolute terms tend to experience smaller per-capita income gaps vis-à-vis the EU-15 average. Second, drawing on the growth literature, differences in the degree of institutional development have also been entered on the r.h.s. of equation (3). This, however, does not produce any significant change in the role of financial openness, even though the point estimate of the coefficient on $d z$ decreases (still significant at $1 \%$ ) in the group of emerging economies. Finally, different proxies for human capital accumulation and labour force growth have been tried (e.g., enrolment in secondary rather than tertiary school, population growth rather than fertility rate). Similarly, different indicators of the depth of domestic financial intermediation have been considered (e.g., the M2 to GDP ratio and the domestic credit to the private sector to GDP ratio). In general the coefficient on $d z$ always retains its sign and level of statistical significance.

\subsection{Financial openness and trade in goods and services.}

Estimates of the gravity equation (6) are presented in Table 2. Columns I to IV refer to estimates for the group of emerging economies; columns V to VIII refer to estimates for the group of 44 countries.

The basic gravity model in column I indicates that the more emerging economies are financially open, the greater their trade integration with the EU-15 will be. The effect of domestic financial development is instead marginally insignificant after controlling for geographical distance and economic size. The next columns II, III and IV indicate that greater international financial integration also leads to greater bilateral trade flows with the EU-15 and that the effects of financial variables are substantially unchanged when the set of regressors is extended to include a dummy for common 
land border (border) and a dummy for landlocked countries (locked). In particular, the coefficients on these two additional variables are largely insignificant, thus suggesting that the extent of trade of emerging economies with the EU-15 is mostly explained by economic size, geographical distance and financial openness.

The results for the full group of 44 countries highlight an interesting difference: financial openness does not appear to increase trade to any significant extent. In fact, the estimated coefficient on $z$ has a p-value of slightly more than 0.1. Still, it does not pass a zero restriction test at usual confidence levels. Moreover, its point estimate is about $1 / 4$ of the value estimated for the group of emerging economies. Taken at face value, this would mean that the role of financial openness as a trade-facilitating factor is strong in the formerly centrally planned economies, but not in western economies. The other results in columns VI, VII and VIII partially mitigate this conclusion. The two measures of international financial integration exhibit significantly positive estimated coefficients. Even more importantly, when the gravity equation includes the two dummies for common border and landlocked countries, the coefficient on $z$ becomes significant, albeit the corresponding marginal effect remains much smaller than that estimated for the emerging economies. Overall, the evidence does suggest that the trade promoting-effect of financial openness is stronger and more relevant for the emerging economies than for the rest of the sample. A deeper analysis of the reasons why this is the case is certainly an interesting avenue for future research.

Robustness checks analogous to those performed for equation (3) are carried out for the gravity model (i.e. changes in the definition of $q$ and inclusion of additional variables on the r.h.s. of the model). Of some specific interest is the inclusion of a dummy variable to control for the existence of preferential trade agreement between a country and the EU-15. This dummy turns out to have a large and positive coefficient. Furthermore, the variable $D$, distance, has been recomputed using different cities as the EU-15 reference. Overall, results on financial openness are qualitatively unchanged.

\section{Conclusions and directions of future research.}

The main result of the empirical analysis is that financial openness facilitates the economic integration of emerging economies with the EU-15. This integration-effect takes the form of faster per-capita income catching-up and greater bilateral trade in goods and services. Furthermore, the effect of financial openness occurs over and 
above the effect of domestic financial deepening. Thus, our results add to the list of potential benefits of capital account liberalisation.

However, a number of qualifications are necessary. First, with respect to per-capita income convergence, the regressions show that even if a country were to achieve the same degree of financial openness as the EU-15, the gap in per-capita income levels would persist as long as there are differences in technology and in the rates of factors accumulation, particularly human capital accumulation. Hence, financial liberalisation is only one of the several policies that countries need to implement in order to sustain income catching-up. Similarly, with respect to international trade, the empirical evidence indicates that financial openness ought to be embedded in a broader context of policies for trade facilitation, including the abatement of tariff and non-tariff barriers (e.g., inefficient custom procedures, inadequate transport infrastructures).

Possibly, the most crucial qualification concerns the possible side-effects and downward risks of financial openness. While our empirical analysis emphasises the benefits of free international capital movements for the process of economic integration, the experience of several other emerging economies world-wide calls for a careful design and implementation of financial and capital account liberalisation in the formerly centrally planned economies ${ }^{17}$. The increased economic vulnerability that is associated with integration into global financial links needs to be managed by combining capital account liberalization with: (i) domestic financial sector reforms to strengthen regulation and supervision, enforce sound and prudential lending practices, achieve high-standards of governance of banks and other financial institutions; (ii) trade policy and competition policy reforms to eradicate distortions that financial openness might exacerbate; (iii) implementation of a coherent macroeconomic policy mix characterised by low inflation and fiscal stability; and (iv) design of redistributive tools to shield the most vulnerable socio-economic groups against the potential damages of increased volatility. Finally, in the transition towards financial liberalization, temporary and market-based capital controls might eventually be considered to tilt the composition of inflows towards longer term maturities and so prevent a maturity mismatch between investment projects and financing ${ }^{18}$.

\footnotetext{
${ }^{17}$ See for instance the discussion in Johnston et al. (1997), Dailami (2000) and Daianu and Vranceanu (2002).

${ }^{18}$ Successful experiences with those type of controls are reported for Chile and other Latin American and East Asian economies. See, inter alia, Edwards (2002) and World Bank (2000).
} 
A number of issues deserve investigation in future research. One concerns a better understanding of the channels through which financial openness affects per-capita income catching up. Several theoretical possibilities exist and our empirical analysis indicates that financial openness does not produce its impact only through the development of domestic financial systems and a faster accumulation of physical capital. A more structural model is therefore needed to disentangle between other possible transmission mechanisms. Future work should also consider whether, in addition to the two considered in this paper, financial openness affects other dimensions of economic integration, such as the sustainability of fixed exchange rate regimes and the rate of nominal convergence. Finally, it would be interesting to assess how the effects of financial openness on economic integration change across different clusters of countries. This requires re-estimation for sample of countries selected along different criteria (i.e. membership in a given regional economic community, initial level of per-capita income, etc.) and compare the estimated strength of the relationship between financial openness and economic integration dimensions. 


\section{Appendix}

Table 1 : Income gap equation - Basic specifications

Emerging economies

All countries

\begin{tabular}{|c|c|c|c|c|c|c|c|c|}
\hline & I & II & III & IV & $\mathrm{V}$ & VI & VII & VIII \\
\hline constant & $1.316 * * *$ & 0.790 & 0.006 & $1.348 * * *$ & 0.046 & 0.144 & $0.254 * *$ & 0.173 \\
\hline$d h$ & $0.967 * *$ & $1.256 * * *$ & $1.550 * * *$ & $1.007 * * *$ & $0.937 * * *$ & $1.836 * * *$ & $1.901 * * *$ & $1.331 * * *$ \\
\hline$d n$ & -0.288 & -0.118 & 1.027 & -0.282 & 0.143 & -0.177 & -0.202 & 0.189 \\
\hline$d q$ & $0.983 * * *$ & $0.805 * * *$ & $0.880 * * *$ & $0.264 * * *$ & $1.056 * * *$ & $0.627 * * *$ & $0.754 * * *$ & $0.659 * * *$ \\
\hline$d z$ & $0.276^{* * *}$ & & & $0.999 * * *$ & $0.642 * * *$ & & & $1.187 * * *$ \\
\hline$d p 1$ & & $0.785 * *$ & & & & $0.940 * * *$ & & \\
\hline$d p 2$ & & & $0.842 * * *$ & & & & $0.466 * * *$ & \\
\hline$d k$ & & & & 0.258 & & & & $2.848 * *$ \\
\hline
\end{tabular}

Note : the Dependent variable is the difference between (log) per-capita income in the EU-15 and log per-capita income of country i. For definition of variables, see the Appendix..

$*,{ }^{*},{ }^{*} * *$ denotes statistical significance at $10 \%, 5 \%$,and $1 \%$ respectively.

Table 2 : Gravity equation

Emerging economies All countries

\begin{tabular}{|c|c|c|c|c|c|c|c|c|}
\hline & I & II & III & IV & $\mathrm{V}$ & VI & VII & VIII \\
\hline constant & $-21.820 * * *$ & $-19.657 * * *$ & $-17.150 * * *$ & $-21.272 * * *$ & $-14.869 * * *$ & $-15.778 * * *$ & $-14.506^{* * *}$ & $-12.647 * * *$ \\
\hline$Y i Y j$ & $0.987 * * *$ & $0.908 * * *$ & $0.834 * * *$ & $0.980 * * *$ & $0.758 * * *$ & $0.770 * * *$ & $0.756^{* * *}$ & $0.692 * * *$ \\
\hline$D$ & $-0.948 * * *$ & $-0.756^{* * *}$ & $-0.557 * * *$ & $-0.967 * * *$ & $-0.226 * * *$ & $-0.211 * * *$ & $-0.260 * * *$ & $-0.139 * * *$ \\
\hline$q$ & 0.050 & 0.004 & $0.109 * * *$ & 0.041 & 0.023 & 0.011 & 0.013 & $0.135 * * *$ \\
\hline$z$ & $0.194 * * *$ & & & $0.180 * * *$ & 0.055 & & & $0.042 * *$ \\
\hline$p 1$ & & $0.663 * * *$ & & & & $0.144 * * *$ & & \\
\hline$p 2$ & & & $2.200 * * *$ & & & & $0.214 * * *$ & \\
\hline border & & & & -0.004 & & & & $0.854 * * *$ \\
\hline locked & & & & -0.063 & & & & -0.087 \\
\hline
\end{tabular}

Note : The dependent variable is the log of trade (in millions of USD) between country $i$ and the EU15. For definition of variables, see the Appendix.

$* * *, * * *$ denotes statistical significance at $10 \%, 5 \%$, and $1 \%$ respectively. 


\section{Variables description}

\begin{tabular}{|c|c|c|}
\hline Variables & Definition & Source \\
\hline$d y$ & $\begin{array}{l}\text { Per-capita income gap. Difference between EU } \\
\text { average log per-capita income and country's log per- } \\
\text { capita income }\end{array}$ & WDI \\
\hline$d n$ & $\begin{array}{l}\text { Difference between EU average log fertility rate and } \\
\text { country's log fertility rate }\end{array}$ & WDI \\
\hline$d h$ & $\begin{array}{l}\text { Difference between EU average tertiary school } \\
\text { enrolment rate and country's tertiary school enrolment } \\
\text { rate }\end{array}$ & WDI \\
\hline$d k$ & $\begin{array}{l}\text { Difference between EU average real investment share } \\
\text { of GDP and country's real investment share of GDP }\end{array}$ & WDI and PWT \\
\hline$q$ & $\begin{array}{l}\text { Index of domestic financial development: country's } \\
\text { ratio of liquid liabilities to narrow money. Alternative } \\
\text { definitions used for sensitivity analysis: domestic } \\
\text { credit to private sector to GD ratio and liquid } \\
\text { liabilities to GDP ratio. }\end{array}$ & IFS \\
\hline$d q$ & Difference between EU average $q$ and country's $q$ & IFS \\
\hline trade & Country's exports to and imports from EU. & DoTS \\
\hline$Y_{i} Y_{j}$ & $\begin{array}{l}\text { Log of country's aggregate GDP times EU's aggregate } \\
\text { GDP }\end{array}$ & WDI \\
\hline locked & Dummy variable taking value if country is landlocked & $\begin{array}{l}\text { CIA World } \\
\text { Factbook }\end{array}$ \\
\hline border & $\begin{array}{l}\text { Dummy variable taking value } 1 \text { if country shares a } \\
\text { land border with any EU-15 member }\end{array}$ & $\begin{array}{l}\text { CIA World } \\
\text { Factbook }\end{array}$ \\
\hline$D$ & $\begin{array}{l}\text { Log of distance (in kilometres) between country and } \\
\text { Frankfurt-am-Main }\end{array}$ & $\begin{array}{l}\text { CIA World } \\
\text { Factbook }\end{array}$ \\
\hline$z$ & Index of capital account openness & See Section 3 \\
\hline$p$ & $\begin{array}{l}\text { Index of international financial integration. Two } \\
\text { versions are proposed: } p_{1} \text { and } p_{2}\end{array}$ & See Section 3 \\
\hline$d z$ & $\begin{array}{l}\text { Difference between EU average open and country's } \\
\text { open }\end{array}$ & \\
\hline
\end{tabular}


$d p \quad$ Difference between EU average integr and country's $p$. Two versions are computed: $d p_{1}$ uses $p_{1}$ and $d p_{2}$ uses $p_{2}$.

Note: WDI is World Development Indicators Database 2004, World Bank; IFS is International Financial Statistics Database June 2004, International Monetary Fund; PWT is Heston A., Summers L., Aten B. Penn World Tables Version 6, CICUP, October 2002; DoTS is Direction of Trade Statistics 2004, International Monetary Fund. 


\section{References}

Bailliu (2000) "Private Capital Flows, Financial Development, and Economic Growth in Developing Countries”, Bank of Canada Working Paper 2000-15.

Barro R. and Sala-i-Martin X. (1995) Economic Growth New York: McGraw Hill.

Bartolini L. and Drazen A. (1997) "Capital Account Liberalization as a Signal”, American Economic Review, 87, 138-154.

Beck T. (2001) "Financial development and international trade. Is there a link ?" mimeo, The World Bank, Washington DC

Bekaert G. and Lundblad (2001) "Does Financial Liberalization Spur Growth ?", NBER Working Paper N. 8425.

Chinn M. and Ito H. (2002) "Capital Account Liberalization, Institutions, and Financial Development: Cross-Country Evidence" mimeo, Department of Economics, University of California at Santa Cruz.

Daianu D. and Vranceanu R. (2002) "Opening the Capital Account of Transition Economies: How Much and How Fast", William Davidson Working paper N. 511, Ann Arbor: University of Michigan.

Dailami M. (2000) "Managing risks of capital mobility", mimeo, The World Bank, Washington DC.

De Brouwer, G. (1999) Financial integration in East Asia, Cambridge: Cambridge University Press.

Edwards S. (2002) "Capital Mobility, Capital Controls and Globalization in the $21^{\text {st }}$ Century", Annals AAPSS, 579, 261-270.

Eichengreen B. (2001) "Capital Account Liberalization: What Do Cross-Country Studies Tell Us ?” World Bank Economic Review, 15, 341-365.

Evenett S. and Keller W. (2002) "On the theories explaining the success of the gravity equation", Journal of Political Economy.

Guiso L. Jappelli T., Padula M., Pagano M. (2004) "Financial market integration and economic growth in the EU", Economic Policy, 40.

Hali J., Klein M., Ricci L.A., Slok, T. (2004) "Capital Account Liberalization and Economic Performance: Survey and Synthesis”, IMF Staff Papers, 51(2), 220-256.

Henry, P. B. (2003) "Capital Account Liberalization, The Cost of Capital, and Economic Growth", American Economic Review Papers and Proceedings, May.

Imbs J. (2003) “Trade, Finance, Specialization and Synchronization” IMF Working Paper 03/81. 
Johnston R. B., Darbar S., Echeverria C. (1997) "Sequencing Capital Account Liberalization: Lessons from the Experiences in Chile Indonesia, Korea, Thailand", IMF Working Paper 97/157.

Kalemli-Ozcan S., Sorensen B., Yosha O. (2003) "Risk Sharing and Industrial Specialization: Regional and International Evidence", American Economic Review, 93.

Kletzer K. and Bardhan P. (1987) "Credit markets and patterns of international trade" Journal of Development Economics 27, 57-70.

Lane P. and Milesi-Ferretti G. M. (2003) "International Financial Integration", IMF Working Paper 03/86.

Le, H.G. (2000) "Financial openness and financial integration", Asia Pacific School of Economics and Management Working Paper 00-4.

Mankiw N.G., Romer D., Weil D. (1992) "A contribution to the empirics of economic growth" Quarterly Journal of Economics, 408-437.

Miniane J. (2004) "A new set of measures on capital account restrictions", IMF Staff Papers, 51, 276-308.

Obstfeld M. (1994) "Risk-taking, global diversification, and growth", American Economic Review, 84, 1310-1329.

Rose, A. (2004) "Macroeconomic determinants of international trade", NBER Reporter, Fall.

Rodrik D. (1998) "Who Needs Capital-Account Convertibility ?" in Should the IMF Pursue Capital Account Convertibility? Essays in International Finance N. 207, may, edited by Stanley Fisher and others, Princeton, New Jersey.

Schiff M. and Winters L. A. (2003) Regional integration and development, Oxford University Press for the World Bank.

Verbeek N. an Nijman T. (1996) "Incomplete panel and selection bias" in Matyas L. and Sevestre P. (editors) The Econometrics of Panel Data, Kluwer.

Wooldridge J. (2002) Econometric analysis of cross-section and panel data, Cambridge: The MIT Press.

World Bank (2000) The Quality of Growth, Oxford University Press for the World Bank. 